\title{
Systematic Review of Breast Cancer Biology in Developing Countries (Part 1): Africa, the Middle East, Eastern Europe, Mexico, the Caribbean and South America
}

\author{
Riyaz Bhikoo $^{1}{ }^{1}$, Sanket Srinivasa ${ }^{1}$, Tzu-Chieh Yu ${ }^{1}$, David Moss ${ }^{2}$ and Andrew G Hill ${ }^{1}$ \\ 1 Department of Surgery, South Auckland Clinical School, University of Auckland, Auckland 1640, \\ New Zealand; E-Mails: sanket.srinivasa@middlemore.co.nz (S.S.); \\ wendells9@gmail.com (T.-C.Y.); andrew.hill@middlemore.co.nz (A.G.H.) \\ 2 Department of Surgery, Middlemore Hospital, Auckland 1640, New Zealand; \\ E-Mail: david.moss@middlemore.co.nz (D.M.) \\ * Author to whom correspondence should be addressed; E-Mail: riyazbhikoo@gmail.com; \\ Tel.: +649-276-0000; Fax: +649-276-0156.
}

Received: 19 January 2011; in revised form: 21 March 2011 / Accepted: 14 April 2011 /

Published: 13 May 2011

\begin{abstract}
There has been no systematic appraisal of ethnicity-based variations in breast cancer (BC) biology amongst women from developing countries. A qualitative systematic review was conducted of breast cancer size, stage, grade, histological type, extra-mammary involvement, hormone receptor status as well as patient demographics. This review includes patients from Africa, the Middle East, Eastern Europe, Mexico, the Caribbean and South America. BC in these regions present at an earlier age with large aggressive tumours. Distant metastases are frequently present at the time of diagnosis. African women have a higher frequency of triple negative tumours. Over half of Middle Eastern women have lymph node involvement at the time of diagnosis. Despite experiencing a lower incidence compared to the Ashkenazi Jewish population, Palestinian women have poorer five-year survival outcomes. The majority of women from Mexico and South America have stage two or three disease whilst over sixty percent of women from Eastern Europe have either stage one or stage two disease. The biological characteristics of $\mathrm{BC}$ in the Caribbean cannot be fully assessed due to a paucity of data from the region. BC amongst the developing world is characterised by an early peak age of onset with aggressive biological characteristics. Strategies that improve breast cancer awareness, address amenable risk factors and improve early detection are essential.
\end{abstract}


Keywords: breast cancer; breast neoplasm; ethnicity; developing countries; low income countries

\section{Introduction}

Breast Cancer (BC) is the most commonly diagnosed cancer amongst women worldwide [1,2]. There were approximately 1.38 million new cases of BC in the year 2008 and by 2020 this figure is anticipated to escalate to 1.7 million [3,4]. Even though the highest reported prevalence of $\mathrm{BC}$ is in developed nations, a significant body of research has found an increasing incidence and poorer survival from BC in developing countries [2-4]. This has been attributed to changes in societal behaviour such as child-bearing practices as well as an adoption of the western lifestyle [5]. Contributing factors also include a lack of awareness of BC especially in the presence of competing infectious diseases with poor access to screening and health care services [6-9]. Many studies have investigated the comparatively poorer survival of indigenous populations within affluent nations and have concluded that differential access to healthcare and socioeconomic status contributes to the inferior outcomes observed [10,11]. However, even after adjusting for these factors, inequalities in mortality still persist and it has been suggested that the discrepancies in survival may be partially explained by ethnicity-related variations in the biological characteristics of BC [12-15].

As a result, there has been growing interest in evaluating the tumour characteristics amongst different ethnic groups. Furthermore, the advancement of genetic testing has placed more importance on the role of genetic factors which may underpin variations in tumour biology. These biological variations may have important consequences for screening, diagnosis and management of BC. However there is a comparative paucity of data from developing countries. Thus, we conducted a systematic review of BC biology in women in developing nations, which we will present as a two part series. In this review we focus on the findings of affected patients residing in Africa, the Middle East, Eastern Europe, Mexico, the Caribbean and South America. In the second part of this review, we will review the characteristics of BC from the Asian Subcontinent and South East Asia [16].

\section{Methods}

Developing countries were defined as per The United Nations Conference on Trade and Development Handbook of Statistics (2008) [17].

\subsection{Literature Search}

The lists of search terms used are listed below:

Breast cancer; Breast malignancy; Breast neoplasm; Breast tumours; Human mammary cancer; Mammary cancer; Mammary carcinoma; Mammary neoplasm; Mammary carcinoma; Ductal carcinoma; Lobular carcinoma; Mastectomy; Infiltrating ductal carcinoma; oestrogen receptors; progesterone receptors; Human epidermal growth factor (HER2); Ethnicity; Race; Nationality. 
The databases were searched up to December 2009 using the key terms entered into the following databases: Medline, Ovid, Pubmed, EMBASE, Science Direct, Cochrane database, Web of Science, and EBSCOhost. Manual searching using the Medical Subject Headings (MESH) database with the key term 'Breast Cancer' and the country in question (e.g., 'Nigeria'). Electronic National Cancer Registries were utilised where such information were made available. References of all relevant articles were also screened for further eligible articles. Abstracts published in English were used when full texts were reported in other languages. Where data on BC incidence and/or mortality was not obtainable the International Agency for Research on Cancer (IARC), Cancer Incidence in Five Continents Volumes IX 1998-2000 as well as data from World Health Organisation (WHO) were utilised to gather this information [18].

\subsection{Selection}

Inclusion criteria

- Studies reporting on the tumour biology of female BC subjects.

Exclusion criteria

- Studies from developed nations.

- Papers not listed under the group of developing countries unless either a comparison was made between that country and a developing country, or in cases where data from the developing nations was not readily available then data of expatriates living in developed nations were used.

- Studies reporting exclusively on male BC.

- Non-English publications.

Outcome measure

- Age at diagnosis, tumour size, histological type, grade and stage of cancer and hormone receptor profile.

\subsection{Validity Assessment and Data Abstraction}

The literature search was conducted by two authors (RB and SS) who identified eligible articles and any disagreement was resolved by discussion with the senior authors DM and AGH.

\subsection{Study Characteristics}

Staging of BC was reported using the American Joint Committee of Cancer (6th edition) with histological staging [19]. Alternatively, staging has been reported as local, regional or distant. Tumour grading has been reported using the Scarff-Bloom-Richardson system and is coded from one to three [20].

\section{Results}

The method by which papers were selected for further evaluation has been summarised in Figure 1 [21]. 
Figure 1. QUOROM flow chart.

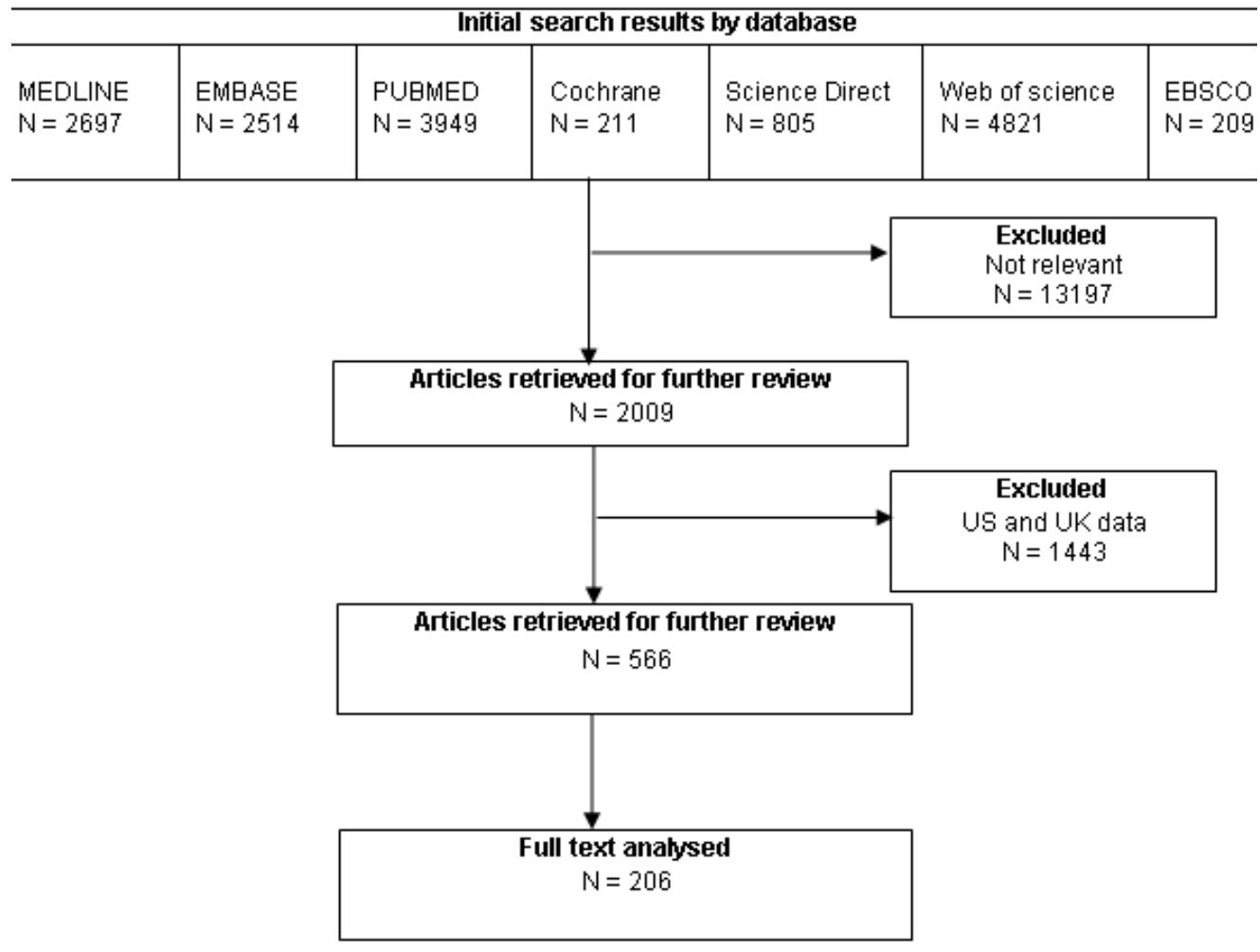

The estimated global age standardised incidence and mortality rates of breast cancer in 2008 are presented in Figure 2. Despite having a lower incidence of breast cancer, we find a higher mortality to incidence ratio amongst developing nations (Figure 2).

\subsection{Africa}

An outline of BC biology amongst African nations is presented in Table 1.

\subsubsection{Sudan}

\subsubsection{Background and tumour biology}

Awadelkarim et al. compared the clinico-pathological characteristics of BC between Sudanese and Italian women and found the former presented at a younger age (52 years vs. 63 years), had larger tumours (48 mm vs. $22 \mathrm{~mm}$ ), more grade three tumours [68\% (78/114) vs. 21\% (25/120)], more stage three/four disease $[38 \%(33 / 88)$ vs. $9 \%(12 / 137)]$ and were more likely to have nodal involvement [90\% (26/29) vs. 36\% (40/110)] [22].

\subsubsection{Hormone receptor status}

Sudanese women had less oestrogen receptor $(\mathrm{ER}+)$ positive tumours [64\% (73/114) vs. 83\% $(114 / 138)]$. However, there were no significant differences in progesterone receptor (PR) positivity [67\% (76/114) vs. 72\% (100/138)], human epidermal growth factor receptor (Her-2/neu) positivity 
[18\% (20/114) vs. $10 \%(14 / 138)]$ or combined hormone receptor status (ER and PR considered together) or BC subtypes (i.e., Luminal A and B, basal-like and unclassified) [22].

Figure 2. Estimated incidence and mortality from breast cancer in 2008.

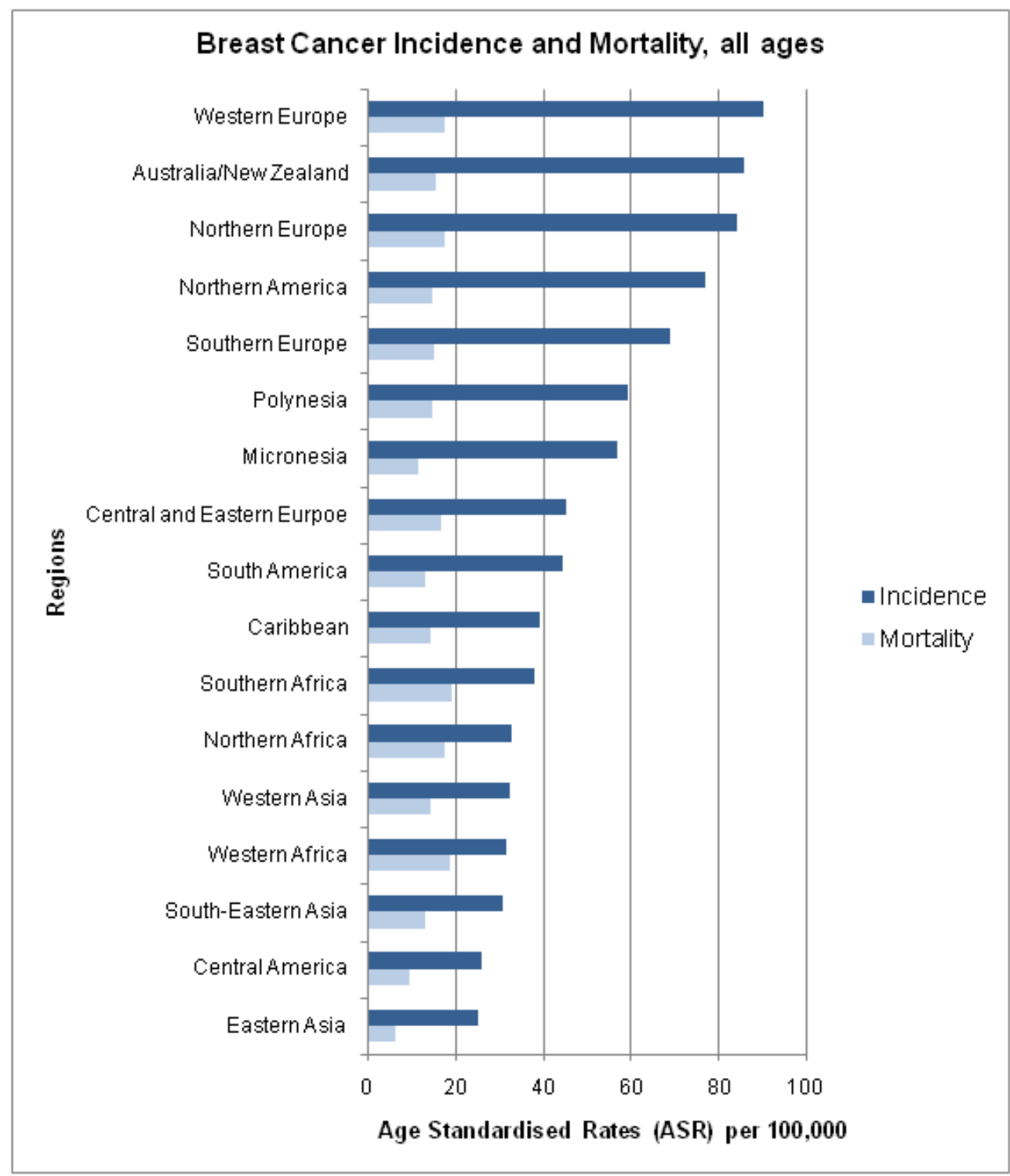

\subsubsection{Nigeria}

\subsubsection{Background}

Gukas et al. showed women in Jos (Nigeria) presented with BC 21 years earlier than a reference population of women from Norfolk UK (43 years vs. 64 years) [29].

\subsubsection{Tumour biology}

Ipkatt et al. compared the biological differences of BC between Finnish $(\mathrm{n}=285)$ and Nigerian $(n=300)$ patients [23]. Nigerian women had less tubular differentiation and had a higher mitotic index to apoptotic index ratio on histology compared to Finnish women [23]. 


\subsubsection{Hormone receptor status}

In a sample of 129 breast specimens, Ipkatt et al. found 24\% were ER+ and 14\% were PR+ [30]. Gukas et al. reviewed 178 specimens and found $25 \%$ and $28 \%$ were ER+ and PR+ respectively [31]. Using stringent fixation methods, Adebamowo et al. found that in contrast to the above studies, most tumours were ER/PR positive, as shown in Table 1 [25]. Amongst women younger than 50 years, $67 \%$ were ER+ and $62 \% \mathrm{PR}+$ while amongst women older than 50 years, $77 \%$ were ER+ and $65 \% \mathrm{PR}+[25]$. $80 \%$ were negative for Her- 2 while $78 \%$ of tumours were luminal type A, three percent were luminal type B, $16 \%$ were basal type and four percent were Her-2+/ER- subtype [25]. Hormone receptor status was associated with tumour grade but not with stage at presentation [25]. Huo et al. found that most tumours were triple negative for hormone receptors (ER/PR/Her-2) and that these findings reflected inherent biological characteristics rather than poor antigen retrieval related to inadequate tissue fixation [24]. Amongst 378 patients, they showed that $27 \%$ of tumours were basal like, $27 \%$ were of Luminal A subtype, 15\% were Her-2 positive/ER negative and 2\% were of the luminal B subtype [24]. Furthermore, Luminal A subtype tumours were less likely to have Ki67 expression (a marker of proliferation) compared to other subtypes [24]. The p53 mutation was more likely to be present among luminal B, Her-2+/ER- and basal-like subtypes [24].

Table 1. Africa.

\begin{tabular}{|c|c|c|c|c|c|c|c|c|}
\hline Country & & Sudan & \multicolumn{3}{|c|}{ Nigeria } & $\underline{\text { Kenya }}$ & Tunisia & Tanzania \\
\hline Author & & $\begin{array}{c}\text { Awadelkarim } \\
{[22]} \\
\end{array}$ & $\begin{array}{c}\text { Ipkatt } \\
{[23]} \\
\end{array}$ & $\begin{array}{l}\text { Huo } \\
{[24]} \\
\end{array}$ & $\begin{array}{c}\text { Adebamowo } \\
{[25]} \\
\end{array}$ & $\begin{array}{l}\text { Bird } \\
{[26]} \\
\end{array}$ & $\begin{array}{c}\text { Maalej } \\
\text { [27] }\end{array}$ & $\begin{array}{c}\text { Mbonde } \\
{[28]} \\
\end{array}$ \\
\hline $\mathbf{N}=$ & & 114 & 285 & 378 & 192 & 129 & 1437 & 60 \\
\hline $\begin{array}{l}\text { Mean/Median } \\
\text { Age (yrs) at } \\
\text { presentation }\end{array}$ & & 52 & 43 & 45 & - & 48 & 51 & 52 \\
\hline $\begin{array}{l}\text { Mean/Median } \\
\text { Tumour Size } \\
\text { (mm) }\end{array}$ & & 48 & 48 & $\begin{array}{c}55 \% \\
(21-40 \\
\mathrm{mm})\end{array}$ & - & $\begin{array}{c}68 \\
\text { (clinical) }\end{array}$ & 33 & $70 \%>51$ \\
\hline \multirow[t]{2}{*}{ Histology } & $\mathrm{IDC}$ & $90 \%$ & - & $87 \%$ & $82 \%$ & 90 & $87 \%$ & $78 \%$ \\
\hline & ILC & $5 \%$ & $4 \%$ & $4 \%$ & $2 \%$ & - & - & $15 \%$ \\
\hline \multirow[t]{3}{*}{ Grade } & 1 & $1 \%$ & \multirow{2}{*}{$55 \%$} & $17 \%$ & $9 \%$ & $16 \%$ & $9 \%$ & $25 \%$ \\
\hline & 2 & $31 \%$ & & $38 \%$ & $44 \%$ & $34 \%$ & $55 \%$ & $47 \%$ \\
\hline & 3 & $68 \%$ & $45 \%$ & $44 \%$ & $16 \%$ & $50 \%$ & $35 \%$ & $28 \%$ \\
\hline \multirow[t]{4}{*}{ Stage } & 1 & \multirow[t]{2}{*}{$62 \%$} & \multirow[t]{2}{*}{$\begin{array}{c}47 \% * \\
-\end{array}$} & - & $5 \%$ & $\begin{array}{c}8 \% \\
\text { (Stage } \\
0-1) \\
\end{array}$ & - & - \\
\hline & 2 & & & - & $10 \%$ & $30 \%$ & - & $7 \%$ \\
\hline & 3 & \multirow[t]{2}{*}{$38 \%$} & \multirow{2}{*}{$\begin{array}{c}53 \% * \\
-\end{array}$} & - & $38 \%$ & $46 \%$ & - & $63 \%$ \\
\hline & 4 & & & - & $48 \%$ & $17 \%$ & - & $30 \%$ \\
\hline $\mathrm{LN}+$ & & $90 \%$ & - & $72 \%$ & - & $72 \%$ & $57 \%$ & - \\
\hline $\mathbf{E R +}$ & & $64 \%$ & - & $24 \%$ & $65 \%$ & $24 \%$ & $57 \%$ & $33 \%$ \\
\hline $\mathrm{PR}+$ & & $67 \%$ & - & $20 \%$ & $55 \%$ & - & $54 \%$ & $18 \%$ \\
\hline
\end{tabular}

* Clinical stage; - Information not available. 


\subsubsection{Kenya}

\subsubsection{Background}

For the period 2003 to 2006, BC was the leading cancer amongst Nairobi women accounting [32].

\subsubsection{Tumour biology}

Bird et al. reported on the results of 129 cases of BC and reported a mean age of 48 years [26]. The histological grade was reported in 114 cases of which $50 \%$ were grade three [26]. Cancer stage is shown in Table 1 [26].

Alterman et al. reported on the biological characteristics of 118 patients ( $89 \%$ female) between 1993 and 1997 [33]. The mean age was 51 years [33]. The histological grade was reported in 28 premenopausal cases ( $<50$ years) of which $54 \%$ were grade three and $39 \%$ were grade two [33].

\subsubsection{Hormone receptor status}

Bird et al. found 66\% (79/120) of cases were ER-/PR-, 24\% (29/120) were ER+, 34\% were either $\mathrm{ER}-$ and/or PR- (41/120) and 10\% were ER- but PR+ (12/120) [26]. The authors reported that ER/PR positivity was not associated with stage and not related to age, parity, menopausal status, or node metastases [26].

\subsubsection{Tunisia}

Tumour biology

Maalej et al. reported on the biological features of 1437 cases of BC (Table 1) [27]. Nodal involvement was reported in $57 \%$ of cases, and of these $20 \%$ had greater than 10 nodes involved [27].

\subsubsection{Tanzania}

\subsubsection{Tumour biology}

In a series of 50 women, Amir et al. found $76 \%$ had stage IIIb disease whilst none had stage one disease [34]. Metastatic disease, constituted 10\% of all cases [34]. All tumours were IDC [34].

\subsubsection{Hormone receptor status}

Mbonde et al. assessed tumour markers in 60 patients (Table 1); 33\% of cases showed expression for ER, while PR+ tumours were reported in 18\%. Rates of expression for Ki-67 (15\%), p53 mutation (30\%) and bcl-2 (44\%) were similar to that reported amongst developed countries [28]. The anti apoptotic protein bcl-2 was strongly co-expressed with ER+ and PR+ tumours [28]. 


\subsubsection{Zimbabwe}

Background

An analysis of 84 patients treated for breast carcinoma found two age peaks of presentation at between 35 to 40 years and 60 to 65 years [35]. Late presentation was observed in $84 \%$ of patients with no further details available.

\subsubsection{Democratic Republic of the Congo}

Background and tumour biology

Kenda et al. reported on 134 cases of BC with a mean age of 47 years [36]. IDC accounted for 69\% of cases while $96 \%$ were found to have either stage three or four disease [36].

\subsubsection{South Africa}

\subsubsection{Background}

In 2001, BC was the leading female cancer amongst asian and coloured women and the second leading cancer amongst white and black women (13\%) [37]. A study of 2130 patients found black women were diagnosed with $\mathrm{BC}$ a decade earlier than white women (50 years vs. 60 years respectively). The authors attributed this disparity to the difference in the age structure of the two populations (mean age of 26 years vs. 35 years respectively) [38].

\subsubsection{Tumour biology}

Stage three and four cancer was reported in $47 \%$ and $36 \%$ of black patients respectively compared to $25 \%$ and $19 \%$ of white patients. [38] Black patients had a poorer prognosis within each stage compared to whites. However, using multivariate analysis the authors found that race itself did not independently predict survival [38]. Compiled data from four tertiary hospitals in South Africa for the period 1970 to 1997 reported 8411 new cases of BC of which one third of patients were black [39]. $78 \%$ of black women had either stage three or four disease compared to $31 \%$ of non-black women [39].

\subsubsection{Madagascar}

\section{Background and tumour biology}

In a retrospective analysis of $373 \mathrm{BC}$ cases between 1995 and 2001 found the mean age at diagnosis was 48 years [40]. IDC was the most common histological type with $30 \%$ of tumours measuring greater than twenty millimetres (T2). 66\% of cases were reported as grade three [40].

\subsection{Middle East}

The tumour characteristics of BC from the Middle East have been outlined in Table 2. 
Table 2. Middle East.

\begin{tabular}{|c|c|c|c|c|c|c|c|c|c|c|}
\hline \multirow[t]{2}{*}{ Author } & \multirow[t]{2}{*}{$\mathbf{N}=$} & \multirow{2}{*}{$\begin{array}{c}\underline{\text { Age }} \\
\text { Mean } \\
\text { Median }\end{array}$} & \multicolumn{2}{|c|}{ Histology } & \multicolumn{4}{|c|}{$\underline{\text { Stage }}$} & \multirow[t]{2}{*}{$\underline{\text { ER+ }}$} & \multirow[t]{2}{*}{$\underline{\mathbf{P R}+}$} \\
\hline & & & $\underline{\text { IDC }}$ & $\underline{\text { ILC }}$ & $\underline{1}$ & $\underline{\mathbf{2}}$ & $\underline{\mathbf{3}}$ & $\underline{4}$ & & \\
\hline \multicolumn{11}{|l|}{ Palestine } \\
\hline Nissan et al. [41] & 65 & 52 & - & - & $23 \%$ & $42 \%$ & $33 \%$ & $2 \%$ & $78 \%$ & $72 \%$ \\
\hline \multicolumn{11}{|l|}{ Saudi Arabia } \\
\hline $\begin{array}{l}\text { Cancer Registry } \\
{[42]}\end{array}$ & 930 & 46 & $77 \%$ & $4 \%$ & - & - & - & - & - & - \\
\hline Ezzat et al. [43] * & 595 & - & $82 \%$ & - & $5 \%$ & $60 \%$ & $35 \%$ & - & $33 \%$ & $28 \%$ \\
\hline Ibrahim et al. [44] & 292 & 42 & - & - & $9 \%$ & $44 \%$ & $30 \%$ & $16 \%$ & - & - \\
\hline \multicolumn{11}{|c|}{ Iran } \\
\hline Mousavi et al. [45] & $\begin{array}{c}85 \\
\text { papers }\end{array}$ & - & $77 \%$ & $5 \%$ & $18 \%$ & $57 \%$ & $25 \%$ & - & \multicolumn{2}{|c|}{-} \\
\hline Saatee et al. [46] & 573 & 49 & $88 \%$ & $6 \%$ & $6 \%$ & $55 \%$ & $22 \%$ & $14 \%$ & \multicolumn{2}{|c|}{$52 \%$} \\
\hline \multicolumn{11}{|c|}{ Oman } \\
\hline $\begin{array}{l}\text { Al-Moundhri et al. } \\
\text { [47] }\end{array}$ & 152 & 49 & $88 \%$ & - & $10 \%$ & $47 \%$ & $42 \%$ & - & $58 \%$ & $53 \%$ \\
\hline \multicolumn{11}{|l|}{ Kuwait } \\
\hline Motawy et al.[48] & 823 & 45 & $73 \%$ & $5 \%$ & $16 \%$ & $52 \%$ & $21 \%$ & $7 \%$ & - & - \\
\hline \multicolumn{11}{|c|}{ Turkey } \\
\hline Ozmen et al. [49] & 9509 & - & _ & - & $23 \%$ & $52 \%$ & $17 \%$ & $4 \%$ & $66 \%$ & $44 \%$ \\
\hline
\end{tabular}

* Patients with stage one to three breast cancer only; - Information not available.

\subsubsection{Israel/Palestine}

\subsubsection{Background}

The Jewish population in Israel has one of the highest rates of BC in the world [6]. Roa et al. reported that genetic mutations in specific BRCA 1 (185delAG and 5382insC) and BRCA2 (6174delT) genes predispose to hereditary $\mathrm{BC}$ amongst the Ashkenazi Jewish population [50]. The combined prevalence of these three mutations is $2.5 \%$ [51]. Comparatively less is known regarding the BC biology amongst the Palestinian women living in Israel. For the period 1970 to 1995, the reported incidence of BC amongst Palestinian women increased by $94 \%$ compared to $32 \%$ for Jewish women [52].

\subsubsection{Tumour biology}

Nissan et al. found that compared to Jewish women [Ashkenazi (A) and Sephardic women (S)], Palestinian $(\mathrm{P})$ patients presented at an earlier age $(\mathrm{P}=52$ vs. $\mathrm{A}=56$ vs. $\mathrm{S}=53)$, with larger tumours $(\mathrm{P}=39 \mathrm{~mm} v s . \mathrm{A}=25 \mathrm{~mm} v s . \mathrm{S}=31 \mathrm{~mm})$ and had significantly worse five year disease free survival figures $(\mathrm{P}=50 \%$ vs. $\mathrm{A}=72 \%)$ with the results being significant [41]. 


\subsubsection{Hormone receptor status}

Nissan et al. found no difference in expression of ER and PR with $78 \%$ of Palestinian women being $\mathrm{ER}+$ and $72 \% \mathrm{PR}$ positive (Ashkenazi women: $77 \% \mathrm{ER}+$ and $71 \% \mathrm{PR}+$ ) [41].

\subsubsection{Egypt}

\subsubsection{Background}

$\mathrm{BC}$ accounted for $18 \%$ of all newly diagnosed proven malignancies in women for the period 2003-2004 [53]. The median age of presentation was 49 years [53].

\subsubsection{Tumour biology}

Data from National Cancer pathology registry for 2003-2004 reported that 85\% of tumours were IDC while $6 \%$ were lobular cancer [53]. The mean tumour size was $32 \mathrm{~mm}$ [53]. Grade one tumours constituted $1 \%$ of cases while $84 \%$ and $15 \%$ were grade two and three respectively [53]. Seventy percent of patients had lymph node metastasis at presentation [53].

\subsubsection{Hormone receptor status}

Fifty eight percent of patients were hormone receptor positive with $44 \% \mathrm{ER}+/ \mathrm{PR}+, 9 \% \mathrm{ER}+/ \mathrm{PR}-$ and $5 \% \mathrm{ER}-/ \mathrm{PR}+$ whilst $45 \%$ of patients were Her2 (2+) [53].

\subsubsection{Saudi Arabia}

\subsubsection{Background}

BC was the leading cancer amongst Saudi women in the year 2005, accounting for 24\% (932/3834) of all newly diagnosed malignancies with a median age at diagnosis of 46 years [42].

\subsubsection{Tumour biology}

The National Cancer registry reported the distribution of cancer stage as being regional in $45 \%$ of cases, localised in $25 \%$ of cases, and distant in $12 \%$ of cases [42]. Ezzat et al., in an analysis of 801 Saudi women for the period 1986-1991, found 26\% (206/801) had stage four cancer [43]. Of the 595 patients with cancer stages one to three (Table 2), 67\% were lymph node positive with $34 \%$ having greater than four lymph nodes involved [43]. Ibrahim et al. identified a median age at presentation of 42 years with $78 \%$ younger than 50 years [44]. Nodal involvement was present in $67 \%$ of patients [44].

\subsubsection{Hormone receptor status}

Ezzat et al. reported that $33 \%$ of cases were $\mathrm{ER}+$ and $28 \%(\mathrm{n}=271)$ were $\mathrm{PR}+[43]$. In a further study of 145 patients, positive Her-2 expression (3+) was observed in $28 \%$ of patients and correlated inversely with ER status [54]. 


\subsubsection{Iran}

\subsubsection{Background}

The National cancer registry in Iran reported 4557 new cases of BC in 2004 [45]. Mousavi combined data from 85 papers and showed BC was most prevalent in women aged 40-49 years with $30 \%$ of cases younger than 30 years [45].

\subsubsection{Tumour biology}

Mousavi et al. found $72 \%$ of tumours were greater than $20 \mathrm{~mm}$ in size with lymph node involvement observed in $63 \%$ of cases [45].

\subsubsection{Hormone receptor status}

Amongst 220 patients, Saatee et al. reported positive Her-2 expression (2+) in 57\% of cases with an inverse relationship between ER and Her-2 over expression observed [46]. In a study of 114 patients (97\% were women), Fallahazad et al. reported that $62 \%$ were ER+ and 52\% were PR+ [55].

\subsubsection{Oman}

\subsubsection{Background}

In 2008, BC accounted for $22 \%$ of all female cancers [56].

\subsubsection{Tumour biology}

Data from 2008 found 74\% of tumours were IDC while lobular carcinoma accounted for $4 \%$ of cases [56]. A retrospective review by Al-Moundhri et al. of 152 patients diagnosed with invasive BC reported a mean age at presentation of 49 years of which $48 \%$ of patients were premenopausal and $20 \%$ were 40 years of age or younger [47]. The mean tumour size was $46 \mathrm{~mm}$ [47]. Axillary dissection was performed on 120 patients of which $69 \%$ had lymph node metastases [47].

\subsubsection{Hormone receptor status}

Using 72 BC tissue specimens, Al-Moundhri et al. found over expression of p53, bcl-2 and Her-2 in $42 \%, 54 \%$ and $19 \%$ of cases respectively [57]. Over expression of bcl-2 was correlated with low histological grade and positive ER/PR status [57]. The over expression of p53 was significantly correlated with younger age $(<40)$, pre-menopausal status, poor tumour differentiation, a lack of ER/PR expression and an inverse correlation with bcl-2 expression [57].

\subsubsection{Bahrain}

\subsubsection{Background}

Fakhro et al. reported on the clinical presentation of $117 \mathrm{BC}$ patients with a mean age at presentation of 50 years with $56 \%$ of patients younger than 50 years [58]. 


\subsubsection{Tumour biology}

Fakhro et al. reported that lump size (via clinical examination, ultrasound and mammography) was between $20-50 \mathrm{~mm}$ in $52 \%$ (61/117) of cases and greater than $50 \mathrm{~mm}$ in $20 \%$ (23/117) [58]. Clinical stage two, three and four cancer were reported in 51\% (60/117), 21\% (25/117) and 11\% (13/117) patients respectively [58]. Only 7\% (8/117) of patients presented with clinical stage one disease [58]. Axillary lymph node involvement was reported in 50\% (59/117) of women with distant metastases reported in $11 \%$ [58].

\subsubsection{United Arab Emirates (UAE)}

\subsubsection{Background}

$\mathrm{BC}$ was the most frequently diagnosed cancer among UAE nationals in the year 2002 accounting for $23 \%$ of all female cancers [59]. Women aged 40-49 and 50-60 had the highest frequency (30\% each) followed by women aged 30-49 (20\%) [59].

\subsubsection{Tumour biology}

IDC accounted for 78\% of tumours, $15 \%$ were epithelial tumours (not otherwise specified) and $5 \%$ were ILC [59]. Regional lymph node involvement was present in $48 \%$ and distant metastases were observed in $9 \%$ [59].

\subsubsection{Cyprus}

Background and tumour biology

Between 1998 and 2001, 44\% of Cypriot women were diagnosed with BC before the age of 55 [60]. Data from 1062 cases of BC found 81\% had IDC on histology while ILC and Adenocarcinoma accounted for seven percent of cases each [60].

\subsubsection{Jordan}

\subsubsection{Background}

BC accounted for $31 \%$ of all female cancers for the period 1996-2002 [61].

\subsubsection{Tumour biology}

For the period between 1996 and 2001, there were 2930 cases of female BC [60]. Of these 94\% had been confirmed histologically of which $82 \%$ were IDC followed by lobular carcinoma (7\%) and Adenocarcinoma (5\%) [60]. Sughayer et al. reported on 267 cases of which 90\% were IDC while 8\% were ILC [62]. Of the tumours reported as IDC, $68 \%$ were grade three, $30 \%$ were grade two and $3 \%$ were grade one [62]. Almasri et al. examined 91 cases of BC and found a median age of 48 years with $57 \%$ (50/88) occurring in patients younger than 50 years [63]. IDC constituted 84\% (76/91) of which $45 \%$ (34/76) were grade two and 49\% (37/76) grade three [63]. 


\subsubsection{Hormone receptor status}

Sughayer et al. reported on the receptor findings of 240 patients with IDC and found $51 \%$ were $\mathrm{ER}+, 58 \%$ were PR+ and $18 \%$ were positive for Her-2 (3+) [62]. Furthermore, 44\% were ER+/PR+, $7 \%$ were $\mathrm{ER}+\mathrm{PR}-, 13 \%$ were ER-PR+ and $36 \%$ were ER-PR- [62]. Almasri et al. found 24\% (22/91) of cases had over expression of Her-2 [63]. Of patients less than 50 years, 34\% (17/50) were positive for Her-2 (3+), $42 \%$ were ER+ (21/50) and 48\% (24/50) were PR+ [63]. In those greater than 50 years, $13 \%(5 / 38)$ were Her-2 (3+), 68\% (26/38) were ER+ and 58\% (22/38) were PR+ [63].

\subsubsection{Kuwait}

Background and tumour biology

Motawy et al. described the pathological characteristics of BC from 823 patients between 1993 and 1998 [48]. The median age was 45 years [48]. The mean tumour size was $38 \mathrm{~mm}$ with $26 \%$ of tumours reported greater than $50 \mathrm{~mm}$ [48]. Fifty five percent of cases had lymph node involvement while distant metastases were reported in seven percent of cases [48]. Thirty five percent of tumours were poorly differentiated [48].

\subsubsection{Lebanon}

\subsubsection{Background}

Data from the National Cancer Registry for the year 2003 found BC accounted for $42 \%$ of all female cancers [64]. El Saghir reported on 2,673 cases of female BCs and found a mean age of 50 years with $21 \%$ of women diagnosed before the age of 39 years [65].

\subsubsection{Tumour biology}

Data from the National Cancer Registry in 2003 found 83\% (1403/1699) were IDC, 6\% (109/1699) were lobular carcinoma and 5\% were (88/1699) Adenocarcinoma [64]. Chalabi et al. reported on 180 French and Mediterranean (Lebanon, Tunisia and Morocco) BC patients and found the latter group tended to be 10 years younger at the time of diagnosis [66]. Furthermore, they were more likely to demonstrate a more aggressive tumour phenotype as evidenced by a greater frequency of grade three tumours and with greater lymph node involvement [66].

\subsubsection{Hormone receptor status}

Abadjian et al. found 43\% (18/42) of women were positive for ER and PR [67]. 49\% (19/39) of tumours were positive for the Ki-67 antigen [67]. Chalabi et al. showed Mediterranean BC patients had an up-regulation of cytokeratins KRT8 and KRT1, suggesting a greater frequency of luminal B subtypes compared to tumours observed in France which are frequently Luminal A type [66]. 


\subsubsection{Turkey}

Background

In 2005, BC accounted for approximately $36 \%$ of female cancers in Turkey [68]. Discrepancy exists in the frequency of BC between the eastern $(20 / 100,000)$ and western regions $(50 / 100,000)$ with the former having a greater frequency of locally advanced BC (50\% vs. 20\%) [49,69]. As of March 2007 there were 9509 registered cases of BC of which $99 \%$ were women [49]. Sixty three percent of women were menopausal while $17 \%$ were under the age of 40 years [49]. Data on tumour biology are presented in Table 2.

\subsection{Eastern Europe}

An overview of BC stage amongst developing nations within Eastern Europe is reported in Table 3.

Table 3. Eastern Europe.

\begin{tabular}{|c|c|c|c|c|c|}
\hline \multirow[t]{2}{*}{ Country } & \multirow[t]{2}{*}{$\mathbf{N}=$} & \multicolumn{4}{|c|}{ Stage } \\
\hline & & 1 & 2 & 3 & 4 \\
\hline \multicolumn{6}{|l|}{ Croatia } \\
\hline Rudan et al. [70] & 21491 & $12 \%$ & $49 \%$ & $28 \%$ & $11 \%$ \\
\hline \multicolumn{6}{|l|}{ Bulgaria } \\
\hline National Registry 2004 [71] & 3548 & $23 \%$ & $48 \%$ & $20 \%$ & $7 \%$ \\
\hline \multicolumn{6}{|l|}{ Ukraine } \\
\hline National Registry 2007 [72] & 15321 & & & $16 \%$ & $8 \%$ \\
\hline
\end{tabular}

\subsubsection{Croatia}

\subsubsection{Background}

In 2005, BC accounted for 24\% of all female cancers with an ASR of 58 per 100,000 [73].

\subsubsection{Tumour biology}

Bezić et al. reported on 2141 cases and found a mean tumour size of $25 \mathrm{~mm}$ [74]. The commonest histological types were IDC (70\%) followed by ILC (11\%) [74]. Forty four percent of tumours were reported as grade two with lymph node involvement in $42 \%$ of cases [74]. Data from the Dubrovnik County in 2007 reported that $14 \%$ of tumours were carcinoma in-situ [75]. 42\% of BCs were less than $10 \mathrm{~mm}$ in size, $51 \%$ were reported as grade one and less than $25 \%$ of cases had axillary node involvement [75]. In 2005, 75-80\% of cases were clinical cancer stage 0-IIA while 20-25\% were stage IIB-IV [75].

\subsubsection{Hormone receptor status}

Bezić et al. found $81 \%$ of tumours were hormone receptor positive [74]. Vrbanec et al. reported an increase in the frequency of ER positive (52\% to 62\%) tumours and a decrease in PR positive tumours 
(56\% vs. 53\%) between 1990 to 2002 [76]. Sixty eight percent of ER+ tumours were reported in the 70 to 79 year age group while $56 \%$ of PR+ tumours were observed in those aged 40 and 49 years [76].

\subsubsection{Bulgaria}

Background and tumour biology

According to the Bulgarian National Cancer Registry for the year 2004, BC was the leading female malignancy accounting for $24 \%$ of newly diagnosed cases [71]. Fifty one percent (1813/3548) of new cases occurred within the 55-74 age group while 22\% (792/3548) were reported in women less than 49 years [71]. Seventy percent (2272/3249) of morphologically confirmed cases were IDC while $14 \%$ (468/3249) were lobular carcinoma [71].

\subsubsection{Ukraine}

Data from the Ukraine Cancer Registry in 2007 reported 15,321 new cases and 7556 deaths from BC [72]. Cancer stage has been reported in Table 3 [72].

\subsubsection{Armenia}

BC is the leading cause of cancer death among Armenian women with 700 new cases diagnosed and 120 deaths each year [77]. No information was available on tumour biology.

\subsubsection{Kazakhstan}

Igisinov et al. reported on 28,707 cases of BC between 1999 and 2008 and found an ASR of 33 per 100,000 [78]. Fifty two percent of patients were between the ages 40-59 years and 18\% were greater than 70 years [78]. No information was available on tumour biology.

\subsubsection{Kyrgyzstan}

Igisinov et al. reported on 1,233 patients from Kyrgyzstan between 1995 and 2002 of which 43\% (524/1,233) were Kyrgyz, 35\% (425/1233) were Russian and 9\% (108/1233) were Uzbeks [79]. Russian women had a higher annual standardised incidence rate $(27 / 100,000)$ compared to Kyrgyz $(10 / 100,000)$ and Uzbeks $(10 / 100,000)$ patients. However, Kyrgyz women had an earlier mean age of diagnosis at 39.9 years compared to Uzbeks women at 40.3 years and Russian women at 42.3 years [79]. No information was available on tumour biology.

\subsection{Mexico}

\subsubsection{Background}

In the year 2006, BC became the leading cause of female cancer deaths in Mexico. [80] Between 2000 and 2006, 50\% of cases occurred in women under the age of 50 [81]. 
Rodríguez-Cuevas et al. reported on 96,828 women who had mammograms between March 2005 and December 2006 of which $0.2 \%$ had BC [82]. The mean age of affected cases was 54 years with $69 \%$ of women less than 60 years of age [82].

\subsubsection{Tumour biology}

Data from the ministry of health found five to $10 \%$ of cases were detected in the early stage (Stage zero to one) [81]. Rodríguez-Cuevas et al. found $29 \%$ of cases detected through mammography were stage one, $42 \%$ were stage two and $27 \%$ were stage three [82]. In contrast, the results of 2245 women treated for BC showed 25-40\% had stage one or two disease while 57\% had either stage three or four cancer [82]. Salazar et al. reported on the tumour characteristics of 192 women with invasive BC of which $81 \%$ (156/192) of tumours were IDC while 19\% (36/192) were ILC [83]. All patients had at least clinical stage two or three cancer [83]. Of the patients with IDC, $84 \%$ had stage three disease while $70 \%$ of all patients with ILC had stage three cancer [83]. Of the patients that had IDC, axillary node involvement was observed in $24 \%$ and $23 \%$ of premenopausal and postmenopausal women respectively and in $19 \%$ for both pre and postmenopausal women with ILC [83].

\subsubsection{Hormone receptor status}

Salazar Esquivel et al. reviewed the ER and PR receptor status in a selection of pre- and postmenopausal patients with clinical stage three IDC [84]. They found $25 \%$ and $26 \%$ of pre and post menopausal women were ER+ PR+ while $31 \%$ and $27 \%$ were $\mathrm{ER}+\mathrm{PR}-, 21 \%$ and $16 \%$ were $\mathrm{ER}-/ \mathrm{PR}+$ and $23 \%$ and $31 \%$ were $\mathrm{ER}-/ \mathrm{PR}$ - respectively [84].

\subsection{Caribbean}

\subsubsection{Barbados}

\section{Background}

Hennis et al. reported that mortality outcomes from $\mathrm{BC}$ amongst the predominately African-Caribbean population of Barbados were comparable to that of African Americans $(33 / 100,000)$ despite the former having a lower incidence of the disease (78 vs. 144/100,000 respectively) [85].

\subsubsection{Cuba}

Hormone receptor status

Alvarez-Goyanes et al. showed that 44\% (182/412) of tumours were ER+ [86]. Furthermore, 68\% $(57 / 85)$ of cases were Her-2 negative, $14 \%$ (12/85) were slightly positive for the Her-2 receptor $(1+/ 2+)$ and $19 \%(16 / 85)$ were strongly positive $(3+)[86]$. 


\subsubsection{Jamaica}

\subsubsection{Background}

Data from Kingston and St Andrews for the period 1998-2002 found the incidence of BC was 40 per 100,000 [87].

\subsubsection{Tumour biology}

The Jamaican Breast Disease Study described the clinicopathologic profile of breast disease in a sample of 1189 Jamaican women [88]. Although the majority of patients had benign disease, $23 \%$ of biopsy samples showed malignant changes on histology [88]. IDC was identified in 70\% of cases [88].

\subsubsection{Trinidad and Tobago}

\subsubsection{Background}

There were 764 cases of BC for the period 2000-2002, which accounted for 15\% of all cancers [89]. Dindyal et al. found that African-Caribbean women represented 54\% of new cases, followed by Indian-Caribbean women at 35\% and mixed races at 11\% [90]. Patients aged 53 to 59 years were most affected [90].

\subsubsection{Tumour biology}

Dindyal et al. showed IDC accounted for $70 \%$ of histological types while ILC accounted for $17 \%$ of cases [90].

\subsubsection{Panama}

Background and tumour biology

The median age at presentation in a series of 31 females was 52 years [91]. Forty two percent of cases had stage one disease, $29 \%$ with stage two, $16 \%$ with stage IIIA, and 13\% with stage IIIB [91].

\subsection{South America}

\subsubsection{Brazil}

\subsubsection{Background}

The Brazilian Ministry of Health estimated 48,930 new diagnoses of BC for the year 2010 with an estimated incidence rate of 49/100 000 women [92]. For the period 2000-2002 Menke et al. showed that $76 \%(104 / 139)$ of cases occurred between the ages of 41 and 70 years [93]. 


\subsubsection{Tumour biology}

Menke et al. reported on 1607 cases between 1972 and 2002 and described a significant reduction in the mean tumour size from $35 \mathrm{~mm}$ to $28 \mathrm{~mm}$ over this period [93]. For the period 2002-2002, 85\% $(118 / 139)$ of tumours were IDC while $10 \%$ (14/139) were ILC [93]. For the same time period grade one tumours were reported in $19 \%(26 / 139)$ of cases, grade two in $46 \%(64 / 139)$ and grade three in $18 \%(25 / 139)$ [93]. Distribution of stage one, two and three was reported as 35\% (49/139), 46\% (64/139) and 19\% (26/139) respectively [93]. The percentage of patients presenting with stage one breast cancer doubled between 1972 and 2002 [93]. Forty-one percent (56/138) had axillary node involvement [93].

\subsubsection{Hormone receptor status}

Menke et al. reported that $65 \%$ of tumours were ER/PR positive [93].

\subsubsection{Columbia}

Background and tumour biology

Two hundred and twenty cases of BC were reported in Pedro Claver Hospital, Bogotá in the year 2004 with a mean age at diagnosis of 59 years [94]. Eighteen percent of cases were diagnosed before the age of 40 [94]. IDC was reported in $84 \%$ of cases and $78 \%$ of tumours were greater than twenty millimetres [94]. Stage one or two disease was reported in $63 \%$ of cases [94].

\subsubsection{Peru}

Tumour biology

Schwartsmann et al. reported on 9005 cases between 1985 and 1997 of which $42 \%$ were stage two while $33 \%$ were stage three [95].

\section{Conclusion}

Breast cancer amongst the developing world is characterised by an early peak age of onset with aggressive biological characteristics. A combined discussion on the topic is included in the second part of this series [16].

\section{References}

1. Gill, J.K.; Maskarinec, G.; Wilkens, L.R.; Pike, M.C.; Henderson, B.E.; Kolonel, L.N.; Gill, J.K.; Maskarinec, G.; Wilkens, L.R.; Pike, M.C.; et al. Nonsteroidal antiinflammatory drugs and breast cancer risk: The multiethnic cohort. Am. J. Epidemiol. 2007, 166, 1150-1158.

2. Hortobagyi, G.N.; de la Garza Salazar, J.; Pritchard, K.; Amadori, D.; Haidinger, R.; Hudis, C.A.; Khaled, H.; Liu, M.C.; Martin, M.; Namer, M.; et al. The global breast cancer burden: Variations in epidemiology and survival. Clin. Breast Cancer 2005, 6, 391-401. 
3. The Lancet. Breast cancer in developing countries. Lancet 2009, 374, 1567.

4. Ferlay, J.S.H.; Bray, F.; Forman, D.; Mathers, C.; Parkin, D.M. GLOBOCAN 2008, Cancer Incidence and Mortality Worldwide: IARC CancerBase No 10 [Internet] Lyon, France: International Agency for Research on Cancer Home Page. Available online: http://globocan.iarc.fr/ (accessed 4 July 2010).

5. Porter, P. "Westernizing” women's risks? Breast cancer in lower-income countries. N. Engl. J. Med. 2008, 358, 213-216.

6. Parkin, D.M.; Fernández, L.M. Use of statistics to assess the global burden of breast cancer. Breast J. 2006, 12 (Suppl. 1), S70-S80.

7. Rizwan, M.M.; Saadullah, M. Lack of awareness about breast cancer and its screening in developing countries. Indian J. Cancer 2009, 46, 252-253.

8. Beaglehole, R.; Yach, D. Globalisation and the prevention and control of non-communicable disease: The neglected chronic diseases of adults. Lancet 2003, 362, 903-908.

9. Badar, F.; Faruqui, Z.S.; Ashraf, A.; Uddin, N. Third world issues in breast cancer detection. J. Pak. Med. Assoc. 2007, 57, 137-140.

10. Vainshtein, J. Disparities in breast cancer incidence across racial/ethnic strata and socioeconomic status: A systematic review. J. Natl. Med. Assoc. 2008, 100, 833-839.

11. Sarfati, D.; Blakely, T.; Shaw, C.; Cormack, D.; Atkinson, J. Patterns of disparity: Ethnic and socio-economic trends in breast cancer mortality in New Zealand. Cancer Cause Contr. 2006, 17, 671-678.

12. Newman, L.A.; Mason, J.; Cote, D.; Vin, Y.; Carolin, K.; Bouwman, D.; Colditz, G.A. AfricanAmerican ethnicity, socioeconomic status, and breast cancer survival: A meta-analysis of 14 studies involving over 10,000 African-American and 40,000 White American patients with carcinoma of the breast. Cancer 2002, 94, 2844-2854.

13. Chlebowski, R.T.; Chen, Z.; Anderson, G.L.; Rohan, T.; Aragaki, A.; Lane, D.; Dolan, N.C.; Paskett, E.D.; McTiernan, A.; Hubbell, F.A.; et al. Ethnicity and breast cancer: Factors influencing differences in incidence and outcome. J. Natl. Cancer Inst. 2005, 97, 439-448.

14. McKenzie, F.; Jeffreys, M't.; Mannetje, A.; Pearce, N. Prognostic factors in women with breast cancer: Inequalities by ethnicity and socioeconomic position in New Zealand. Cancer Cause Contr. 2008, 19, 403-411.

15. Wojcik, B.E.; Spinks, M.K.; Optenberg, S.A. Breast carcinoma survival analysis for African American and white women in an equal-access health care system. Cancer 1998, 82, 1310-1318.

16. Bhikoo, R.; Srinivasa, S.; Yu, T.C.; Moss, D.; Hill, A.G. Systematic review of breast cancer biology in developing countries (Part 2): Asian Subcontinent and South East Asia. Cancers 2011, accepted.

17. United Nations Conference on Trade and Development UNCTAD handbook of statistics, 2008 United Nations Publications TD/STAT33 Home Page. Available online: http://www.unctad.org/ (accessed 4 July 2010).

18. Curado, M.P.; Edwards, B.; Shin, H.R. Cancer Incidence in Five Continents, Vol. IX. IARC Scientific Publications No. 160, Lyon, IARC. Available online: http://www-dep.iarc.fr/ (accessed 22 August 2009). 
19. AJCC Cancer Staging Manual, 6th ed.; Greene, F.L., Page, D.L., Fleming, I.D., Fritz, A., Balch, C.M., Haller, D.G., Morrow, M, Eds.; Springer: New York, NY, USA, 2002.

20. Elston, C.W.; Ellis, I.O. Pathological prognostic factors in breast cancer. I. The value of histological grade in breast cancer: Experience from a large study with long-term follow-up. Histopathology 1991, 19, 403-410.

21. Moher, D.; Cook, D.J.; Eastwood, S.; Olkin, I.; Rennie, D.; Stroup, D.F. Improving the quality of reports of meta-analyses of randomised controlled trials: The QUOROM statement Quality of reporting meta-analyses. Lancet 1999, 354, 1896-1900.

22. Awadelkarim, K.D.; Arizzi, C.; Elamin, E.O.; Hamad, H.M.; De Blasio, P.; Mekki, S.O.; Osman, I,; Biunno, I.; Elwali, N.E.; Mariani-Costantini R.; et al. Pathological, clinical and prognostic characteristics of breast cancer in Central Sudan versus Northern Italy: Implications for breast cancer in Africa. Histopathology 2008, 52, 444-456.

23. Ikpatt, O.F.; Kuopio, T.; Ndoma-Egba, R.; Collan, Y. Breast cancer in Nigeria and Finland: Epidemiological, clinical and histological comparison. Anticancer Res. 2002, 22, 3005-3012.

24. Huo, D.; Ikpatt, F.; Khramtsov, A.; Dangou, J.M.; Nanda, R.; Dignam, J.; Zhang, B.; Grushko, T.; Zhang, C.; Oluwasola, O.; et al. Population differences in breast cancer: Survey in indigenous african women reveals over-representation of triple-negative breast cancer. J. Clin. Oncol. 2009, 27, 4515-4521.

25. Adebamowo, C.A.; Famooto, A.; Ogundiran, T.O.; Aniagwu, T.; Nkwodimmah, C.; Akang, E.E. Immunohistochemical and molecular subtypes of breast cancer in Nigeria. Breast Cancer Res. Treat. 2008, 110, 183-188.

26. Bird, P.A.; Hill, A.G.; Houssami, N. Poor hormone receptor expression in East African breast cancer: Evidence of a biologically different disease? Ann. Surg. Oncol. 2008, 15, 1983-1988.

27. Maalej, M.; Hentati, D.; Messai, T.; Kochbati, L.; El May, A.; Mrad, K.; Romdhane, K.B.; Ben Abdallah, M.; Zouari, B. Breast cancer in Tunisia in 2004: A comparative clinical and epidemiological study. Bull. Cancer 2008, 95, E5-E9.

28. Mbonde, M.P.; Amir, H.; Schwartz-Albiez, R.; Akslen, L.A.; Kitinya, J.N. Expression of estrogen and progesterone receptors in carcinomas of the female breast in Tanzania. Oncol. Rep. 2000, 7, 277-283.

29. Gukas, I.D.; Jennings, B.A.; Mandong, B.M.; Manasseh, A.N.; Leinster, S.J. A comparison of the pattern of occurrence of breast cancer in Nigerian and British women. Breast 2006, 15, 90-95.

30. Ikpatt, O.F.; Ndoma-Egba, R. Oestrogen and progesterone receptors in Nigerian breast cancer: Relationship to tumour histopathology and survival of patients. Cent. Afr. J. Med. 2003, 49, 122-126.

31. Gukas, I.D.; Jennings, B.A.; Mandong, B.M.; Igun, G.O.; Girling, A.C.; Manasseh, A.N.; Ugwu, B.T.; Leinster, S.J. Clinicopathological features and molecular markers of breast cancer in Jos, Nigeria. West Afr. J. Med. 2005, 24, 209-213.

32. Nairobi Cancer Registry Kenya Medical Research Institute Nairobi, Kenya (KERMI). Cancer Incidence Report Nairobi 2003-2006. The International Network for Cancer Treatment and Research Home Page. Available online: http://www.inctr.org/ (accessed 10 November 2009).

33. Alterman, D.M.; Parker, R.M.; White, R.E. A fourteen-year review of breast pathology at a rural referral center in western Kenya. East Cent. Afr. J. Surg. 2008, 13, 41-50. 
34. Amir, H.; Azizi, M.R.; Makwaya, C.K.; Jessani, S. TNM classification and breast cancer in an African population: A descriptive study. Cent. Afr. J. Med. 1997, 43, 357-359.

35. Muguti, G. Experience with breast cancer in Zimbabwe. JR Coll. Surg. Edinb. 1993, 38, 75-78.

36. Kenda, J.F.; Chirimwami, B.; Veyi, T. Clinicopathologic analysis of carcinoma of the breast in an African population. Arch. Surg. 1988, 123, 972-974.

37. National Health Laboratory Service (South Africa). National Cancer Registry. Summary Statistics of Cancer Diagnosed Histologically in 2001 Home Page. Available online: http://www.nhls.ac.za/ (accessed 20 November 2009).

38. Dansey, R.D.; Hessel, P.A.; Browde, S.; Lange, M.; Derman, D.; Nissenbaum, M.; Bezwoda, W.R. Lack of a significant independent effect of race on survival in breast cancer. Cancer 1988, 61, 1908-1912.

39. Vorobiof, D.A.; Sitas, F.; Vorobiof, G. Breast cancer incidence in South Africa. J. Clin. Oncol. 2001, 19 (Suppl. 18), 125S-127S.

40. Raharisolo Vololonantenaina, C.R.; Rabarijaona, L.P.; Rajemiarimoelisoa, C.; Rasendramino, M.; Migliani, R. Management of breast cancers diagnosed at the Pasteur Institute of Madagascar from 1995 to 2001. Arch. Inst. Pasteur. Madagascar. 2002, 68, 104-108.

41. Nissan, A.; Spira, R.M.; Hamburger, T.; Badrriyah, M.; Prus, D.; Cohen, T.; Hubert, A.; Freund, H.R.; Peretz, T. Clinical profile of breast cancer in Arab and Jewish women in the Jerusalem area. Am. J. Surg. 2004, 188, 62-67.

42. Kingdom of Saudi Arabia Ministry of Health. Saudi Cancer Registry. Cancer Incidence Report Saudi Arabia 2005. Available online: http://www.scr.org.sa/ (accessed 22 October 2009).

43. Ezzat, A.; Raja, M.; Rostom, A.; Zwaan, F.; Akhtar, M.; Bazarbashi, S.; Ingemansson, S.; Al-Abdulkareem, A. An overview of breast cancer. Ann. Saudi. Med. 1997, 17, 10-15.

44. Ibrahim, E.M.; Al-Mulhim, F.A.; Al-Amri, A.; Al-Muhanna, F.A.; Ezzat, A.A.; Stuart, R.K.; Ajarim, D. Breast cancer in the eastern province of Saudi Arabia. Med. Oncol. 1998, 15, 241-247.

45. Mousavi, S.M.; Montazeri, A.; Mohagheghi, M.A.; Jarrahi, A.M.; Harirchi, I.; Najafi, M.; Ebrahimi, M. Breast cancer in Iran: An epidemiological review. Breast J. 2007, 13, 383-391.

46. Saatee, S.; Afrakhteh, M.; Sadrolhefazi, B. High prevalence of HER-2/neu overexpression among Iranian women with breast cancer: True or false? Breast J. 2006, 12, 499-501.

47. Al-Moundhri, M.; Al-Bahrani, B.; Pervez, I.; Ganguly, S.S.; Nirmala, V.; Al-Madhani, A.; Al-Mawaly, K.; Grant, C. The outcome of treatment of breast cancer in a developing countryOman. Breast 2004, 13, 139-145.

48. Motawy, M.; El Hattab, O.; Fayaz, S.; Oteifa, M.; Ali, J.; George, T.; Barghash, I.; Abuzallouf S,; El Jarallah, M. Multidisciplinary approach to breast cancer management in Kuwait, 1993-1998. J. Egypt Natl. Cancer Inst. 2004, 16, 85-91.

49. Özmen, V. Cancer control in Turkey. In Breast Cancer Screening and Registration Programs in Turkey; Tuncer, M., Ed.; Onur Press: Ankara, Turkey, 2008; Volume 740, pp. 335-343.

50. Roa, B.B.; Boyd, A.A.; Volcik, K.; Richards, C.S. Ashkenazi Jewish population frequencies for common mutations in BRCA1 and BRCA2. Nat. Genet. 1996, 14, 185-187.

51. Tonin, P.; Weber, B.; Offit, K. Frequency of recurrent BRCA1 and BRCA2 mutations in Ashkenazi Jewish breast cancer families. Nat. Med. 1996, 2, 1179-1183. 
52. Baron-Apel, O. Breast cancer. In Green Me: The State of Health in Israel. Israel Center for Disease Control: Jerusalem, Palestine, 1999; pp. 91-95.

53. Mokhtar, N.; Gouda, I.; Adel, I. Cancer Pathology Registry, 2003-2004, And Time Trend Analysis. Department of Pathology at the National Cancer Institute (NCI) Home Page. Available online: http://www.nci.cu.edu.eg/ (accessed 17 November 2009).

54. Al-Ahwal, M.S. HER-2 positivity and correlations with other histopathologic features in breast cancer patients-Hospital based study. J. Pak. Med. Assoc. 2006, 56, 65-68.

55. Fallahazad, V.; Kamalian, N.; Gransar, A. The prevalence of Estrogen and progesterone receptors in Breast cancer in shariati general hospital of Tehran 2000-2002. J. Tehran Med. Fac. 2004, 62, 745-748.

56. Ministry of Health Sultanate of Oman. Cancer incidence in Oman 2008. Department of Non-Communicable Diseases Surveillance and Control Directorate General of Health Affairs Home Page. Available online: http://www.moh.gov.om/ (accessed 3 March 2010).

57. Al-Moundhri, M.; Nirmala, V.; Al-Mawaly, K.; Ganguly, S.; Burney, I.; Rizvi, A.; Grant, C. Significance of p53, Bcl-2, and HER-2/neu protein expression in Omani Arab females with breast cancer. Pathol. Oncol. Res. 2003, 9, 226-231.

58. Fakhro, A.E.; Fateha, B.E.; Al-Asheeri, N.; Al-Ekri, S.A. Breast cancer: Patient characteristics and survival analysis at Salmaniya medical complex, Bahrain. East Mediterr. Health J. 1999, 5, 430-439.

59. United Arab Emirates National Cancer Registry. Cancer Incidence Report UAE 1998-2001 Home Page. Available online: http://www.tawamhospital.ae/ccr/annualReport.asp/ (accessed 2 November 2009).

60. Cancer Incidence in Four Member Countries (Cyrpus, Egypt, Israel and Jordan) of the Middle East Cancer Consortium (MECC) Compared with US SEER; Freedman, L.S., Edwards, B.K., Ries, L.A.G., Young, J.L., Eds.; National Cancer Institute: Bethesda, MD, USA, 2006.

61. Omar, F. Nimri, com.med. Epidemiology of Cancer in Jordan, 1996-2002. Proceedings of UICC World Cancer Congress, Washington, DC, USA, July 8-12, 2006.

62. Sughayer, M.A.; Al-Khawaja, M.M.; Massarweh, S.; Al-Masri, M. Prevalence of hormone receptors and HER2/neu in breast cancer cases in Jordan. Pathol. Oncol. Res. 2006, 12, 83-86.

63. Almasri, N.M.; Al Hamad, M. Immunohistochemical evaluation of human epidermal growth factor receptor 2 and estrogen and progesterone receptors in breast carcinoma in Jordan. Breast Cancer Res. 2005, 7, R598-R604.

64. Adib, S.M.; Daniel, J. Ministry of Public Health. National Cancer Registry. Cancer in Lebanon 2003. Available online: http://www.moph.gov.lb/Publications/Documents/NCR2003.pdf (accessed 26 August 2010).

65. El Saghir, N.S.; Shamseddine, A.I.; Geara, F.; Bikhazi, K.; Rahal, B.; Salem, Z.M.; Taher, A.; Tawil, A.; El Khatib, Z.; Abbas, J. Age distribution of breast cancer in Lebanon: Increased percentages and age adjusted incidence rates of younger-aged groups at presentation. J. Med. Liban 2002, 50, 3-9. 
66. Chalabi, N.; Bernard-Gallon, D.J.; Bignon, Y.J.; Breast Med Consortium; Kwiatkowski, F.; Agier, M.; Vidal, V.; Laplace-Chabaud, V.; Sylvain-Vidal, V.; Bertholet, V.; et al. Comparative clinical and transcriptomal profiles of breast cancer between French and South Mediterranean patients show minor but significative biological differences. Cancer Genomics Proteomics 2008, 5, 253-261.

67. Abadjian, G.; Antoun, R. Breast carcinoma: Evaluation of hormone receptors and pS2, erb-B2, P-glycoprotein and Ki-67 markers. Med. Liban 1996, 44, 10-15.

68. Yilmaz, H.H.; Yazihan, N.; Tunca, D.; Sevinç, A.; Olcayto, E.Ö.; Ozgül, N.; Tuncer, M. Cancer trends and incidence and mortality patterns in Turkey. Jpn. J. Clin. Oncol. 2010, 41, 10-16.

69. Özmen, V. How the quality of surgical treatment of breast cancer is increased in Turkey? J. Breast Health 2009, 5, 122-124.

70. Rudan, I.; Rudan, N.; Strnad, M. Differences between male and female breast cancer. I. Epidemiological features. Acta Med. Croatica 1995, 49, 117-120.

71. National Oncological Hospital, Bulgarian National Cancer Registry Cancer Incidence in Bulgaria 2004 Home Page. Available online: http://www.onco-bg.com/ (accessed 18 October 2009).

72. Ukraine Cancer Registry. Bulletin of National Cancer Registry of Ukraine 2006-07 Home Page. Available online: http://www.i.com.ua/ ucr/ (accessed 19 October 2009).

73. Croatian National Institute of Public Health, Croatian National Cancer Registry Cancer Incidence in Croatia 2005 Bulletin No 30, Zagreb 2007. Cancer incidence in Mediterranean populations. Available online: http://www.mosepi.org/Croatia (accessed 5 April 2011).

74. Bezić, J.; Tomić, S.; Kardum, G. Minimal breast cancer in split region of Croatia on the eve of the National Mammographic Screening Program. Breast J. 2009, 15, 429-431.

75. Agarwal, G.; Ramakant, P.; Forgach, E.R.; Rendón, J.C.; Chaparro, J.M.; Basurto, C.S.; Margaritoni, M. Breast cancer care in developing countries. World J. Surg. 2009, 33, 2069-2076.

76. Vrbanec, D.; Petricević, B. Estrogen and progesterone receptor status in primary breast cancerA study of 11,273 patients from the year 1990 to 2002. Coll. Antropol. 2007, 31, 535-540.

77. Aydinyan, L. Community based clinical trial among Yerevan women to determine the effect of a breast cancer intervention program. Department of Public Health. American University of Armenia Home Page. Available online: http://chsr.aua.am/PDF/MPH/2001/AydinyanLusine.pdf (accessed 6 November 2009).

78. Igisinov, N.; Bilyalova, Z.; Igisinov, S.; Seytkazina, G.D. Breast Cancer in Kazakhstan: Epidemiological Aspects. Presented at the 20th Asian Pacific Cancer Conference, Tsukuba, Japan November 13, 2009.

79. Igisinov, N.; Kokteubaeva, N.; Kudaibergenova, I. Epidemiology of Breast cancer in females of reproductive age in Kyrgyzstan. Asian Pac. J. Cancer Prev. 2005, 6, 37-40.

80. Knaul, F.M.; Nigenda, G.; Lozano, R.; Arreola-Ornelas, H.; Langer, A.; Frenk, J. Breast cancer in Mexico: A pressing priority. Reprod. Health Matters 2008, 16, 113-123.

81. Sistema Único de Información para la Vigilancia Epidemiológica de la Dirección General de Epidemiología, Anuarios de Morbilidad, 2000-2006. Secretaría de Salud Home Page. Available online: http://www.tomateloapecho.org.mx/attachments/File/documentos/Numeralia\%20ingles.pdf (accessed 14 December 2009).

82. Rodríguez-Cuevas, S.; Guisa-Hohenstein, F.; Labastida-Almendaro, S. First breast cancer mammography screening program in Mexico: Initial results 2005-2006. Breast J. 2009, 15, 623-631. 
83. Salazar, E.L.; Calzada, L.; Pedron, N. Infiltrating ductal/lobular carcinoma: An evaluation of prognostic factors in primary breast cancer. Arch. AIDS Res. 1996, 10, 73-82.

84. Salazar Esquivel, E.L.; Morales Nájar, R.; Calzada Sánchez, L. Infiltrating duct breast carcinoma: The role of estradiol and progesterone receptors. Ginecol Obstet Mex 1994, 62, 85-90.

85. Hennis, A.J.; Hambleton, I.R.; Wu, S.Y.; Barbados National Cancer Study Group. Breast cancer incidence and mortality in a Caribbean population: Comparisons with African-Americans. Int. J. Cancer 2009, 124, 429-433.

86. Alvarez-Goyanes, R.I.; Pérez, X.E.; Rodríguez, C.R.; Fernández, L.L.; López, M.O.; Mojarrieta, J.C.; Rodríguez-Montero, H.M.; Juliá, M.A. Presence of estrogen receptor and Her2 in a sample of breast cancer patients. MEDICC review 2003 Vol 5. Available online: http://www.medicc.org/publications/medicc_review/V/23/pages/cubanmedicalresearch-4.html/ (accessed 16 November 2009).

87. Gibson, T.N.; Blake, G.; Hanchard, B.; Waugh, N.; McNaughton, D. Age-specific incidence of cancer in Kingston and St Andrew, Jamaica, 1998-2002. West Indian Med. J. 2008, 57, 81-89.

88. Shirley, S.E.; Mitchell, D.I.; Soares, D.P.; James, M.; Escoffery, C.T.; Rhoden, A.M.; Wolff, C.; Choy, L.; Wilks, R.J. Clinicopathologic features of breast disease in Jamaica: Findings of the Jamaican Breast Disease Study, 2000-2002. West Indian Med. J. 2008, 57, 90-94.

89. Dr. Elizabeth Quamina Cancer Registry. The National Cancer Registry of Trinidad and Tobago. Cancer in Trinidad and Tobago 2000-2002 Home Page. Available online: http://www.health.gov.tt/downloads/default.aspx?id=27/ (accessed 5 September 2009).

90. Dindyal, S.; Ramdass, M.J.; Naraynsingh, V.; Jankey, N.; Maharaj, D.; Barrow, S. Relationship of ethnicity and histologic type of breast carcinoma in a West Indian population. Breast J. 2004, 10, 266.

91. Caballero, J.L.; Ríos, B. Breast cancer. Rev. Med. Panama 1995, 20, $50-53$.

92. Ministério da Saúde Instituto Nacional De Cancer (INCA) Estimativa 2010 - Incidência de câncer no Brasil Home Page. Available online: http://www.inca.gov.br/estimativa/2010/index.asp/ (accessed 20 July 2010).

93. Menke, C.H.; Pohlmann, P.R.; Backes, A.; Cericatto, R.; Oliveira, M.; Bittelbrunn, A.; Schwartsmann, G. Tumor size as a surrogate end point for the detection of early breast cancer: A 30-year (1972-2002), single-center experience in southern Brazil. Breast J. 2007, 13, 448-456.

94. González-Mariño, M.A. Breast cancer in the Pedro Claver hospital in Bogotá, 2004. Rev. Salud Publica (Bogota) 2006, 8, 163-169.

95. Schwartsmann, G. Breast cancer in South America: Challenges to improve early detection and medical management of a public health problem. J. Clin. Oncol. 2001, 19 (Suppl. 18), 118S-124S.

(C) 2011 by the authors; licensee MDPI, Basel, Switzerland. This article is an open access article distributed under the terms and conditions of the Creative Commons Attribution license (http://creativecommons.org/licenses/by/3.0/). 